\title{
Abstracts of Articles
}

"A Note on Finds of Early Chinese Ceramics Associated with Megalithic Remains in Northwest Lampung" by E. EDWARDS McKINNON

The discovery of imported ninth-century Chinese green-glazed and white-glazed stonewares at megalithic sites near Sumberjaya on the headwaters of a tributary the Wai Tulangbawang in northwest Lampung offers an interesting insight into aspects of a late first millennium internal trade network and a so-far unique "end point" of ceramic distribution in southern Sumatra.

\section{"Southeast Asian Intercalation: Variations and Complexities" by J.C. EADE}

A close look at the Southeast Asian system of intercalation, at the method of forcing lunar reckoning into line with solar reckoning, shows that both the "rules" and their implementation were such that variation in the historical sources is inevitable. The historian has therefore to expect his data will often be difficult to match.

\section{"Southeast Asia's Incorporation into the World Rice Market: A Revisionist View"} by PETER A. COCLANIS

The author argues that the conventional "story" of Southeast Asia's incorporation into the world rice market: (a) starts too late; (b) is too abrupt; (c) is insufficiently specified; and (d) gives too much explanatory weight to exogenous variables relating to trade and exchange, and too little to endogenous variables relating to Southeast Asian rice production itself. He then offers an alternative "story", which takes account of these problems.

\section{“Conditions on Sugar Estates in Colonial Java: Comparisons with Deli" by WIM F. WERTHEIM}

Sociological studies of plantations are mainly concerned with estates, characterized as "frontier societies" employing labour imported from distant regions. At the time of Dutch colonial rule, however, a different type of plantations could be found in Java, where sugar estates leased land from the local peasantry and employed them as labour force. Though initially the social setting was definitely less harsh than in a frontier society, in the course of time the abundant supply of labour led to relationships that could become as grim as those in Deli (Sumatra's Eastcoast), though in a different social context.

\section{“The Development of the Rubber Market in Pre-World War II Singapore" by W.G.} HUFF

Little attention has been paid to the development of Singapore as a major international rubber market after 1914. The present article attempts to fill this gap and argues that Singapore's ability to provide a range of low-cost services for both Malaya and Indonesia was of key importance to rubber production in these 
areas. The article focuses on Singapore's comparative advantage in services and extends this analysis to recent economic development in the Republic.

"The Southern Thai Shadowplay Tradition in Historical Context" by PETER VANDERGEEST and PARITTA CHALERMPOW-KOANANTAKOOL

The authors discuss the shadowplay performed by Tai-speaking people on the Malay peninsula. Puppeteers have developed three performance styles. In the modern style puppeteers aim for direct, realist representations of the modern world; in the traditional style they aim to preserve the shadowplay as Southern Thai culture; and in the potent style they emphasize potent knowledge. These styles are the result of the puppeteers' efforts to maintain the relevancy of the shadowplay in a rapidly changing social context.

\section{"Interpreting Thai Religious Change: Temples, Sangha Reform and Social Change"} by RICHARD A. O'CONNOR

Attributing Thai religious change to recent societal changes - urbanization, a new middle class, modernity - obscures how today's religion arises from last century's Sangha reforms that changed the temple's place in Thai society. As reforms drove popular religion out of the temple, centralization pulled regional religions into the capital to create today's "free market" in religion. 